\title{
Climate change in international law
}

\section{El cambio climático frente al derecho internacional}

Jesús Francisco Ramírez Bañuelos

Recibido:

Aceptado:

Abstract:

Key words:

Resumen:

Palabras clave:
Universidad Jesuita de Guadalajara, México

ramirezbanuelos@gmail.com

$$
1 / 2 / 2021
$$

$16 / 9 / 2021$

Using a critical approach, this essay documents the principles of international law that have an impact on climate change. It then identifies the resources available to States and individuals to demand compliance with climate change obligations and assesses their chances of success. Finally, a new approach is put forward that would help solve conflicts more effectively.

climate change, international law, climate justice, multi-level conflict

Mediante un enfoque crítico, este ensayo documenta los principios del derecho internacional que inciden en el cambio climático. Enseguida se identifican los recursos disponibles para que los Estados e individuos exijan el cumplimiento de las obligaciones en materia del cambio climático y se valoran sus posibilidades de éxito. Finalmente, se adelanta un nuevo enfoque que ayudaría a solucionar los conflictos de manera más efectiva.

cambio climático, derecho internacional, justicia climática, conflicto multinivel

Cómo citar este artículo: Ramírez Bañuelos, J. F (2021). Climate change in international law, Revista Electrónica de Derecho Internacional Contemporáneo, 4(4), $\mathrm{e} 017$. 


\section{Introduction}

Climate change reflects the complexity of post-modernity. It is a multi-level conflict that is addressed in subnational, national, regional and international jurisdictional and quasi-jurisdictional forums (Marjanac, 2020). For this reason, a coherent system is needed to demand respect, protection, prevention of a healthy environment and, if necessary, reparation of the damage caused.

Moreover, it is a complex problem that highlights the tension between national interests and the attention to a global problem. It also shows how some corporations have more power than many states (Clapham, 2006).

It likewise exhibits the vulnerability of the most disadvantaged. This is why the human rights dimension is necessary. It is also an intergenerational problem (La Vina \& Sy, 2019). This makes the preventive function of the law necessary.

Using a critical approach (Corten, 2009), this essay documents the principles of international law that impact on climate change. It then identifies the resources available to states and individuals to demand compliance with climate change obligations and assesses their chances of success. Finally, a new approach is put forward that would help solve conflicts more effectively.

\section{a. Principles of international law that impact on the fight against climate change}

In the fight against climate change, first and foremost, the general principles of international law, as well as those relating in particular to the environment, apply and entail international responsibility for the wrongful actions of states (Elborough, 2017). Also, climate change is subject to specific principles that -although some are controversial - are already being used by complainants and are reflected in court rulings and referred to below.

\section{i. The principle of no-harm}

This principle is one of the ideas that structure environmental law in general and that has particular importance in the fight against climate change. By its nature, this principle is of a customary order. Moreover, it has been applied by international jurisdictions, particularly by the International Court of Justice, when it issued its advisory opinion on the use of nuclear weapons (ICJ, 1996, para 29; Elborough, 2017, p.97-98).

The basis of this principle is that countries are obliged to respect the rights of other member states of the international community. Therefore, this principle is conceived as the obligation of states to avoid causing harm to other nation states (Declaration of the United Nations Conference on the Human Environment, 1972, principle 21; Rio Declaration on Environment and Development, 1992, principle 2; Elborough, 2017, p.97).

\section{ii. Due diligence}

Due diligence, derived from the principle of no-harm, has become a customary standard and has been employed by the International Court of Justice (ICJ, 2010, 55, para 101; Mayer; 2019). It consists of expanding the focus not only on establishing the appropriate rules and measures to avoid causing harm, but also on monitoring compliance by all actors, regardless of their public or private nature.

\section{iii. The principle of equity}

The intergenerational dimension of climate change is reflected in this principle. To protect the rights of people living on the planet and those to come, the fight against climate change is one of the top priorities of humanity.

It consists of giving fair and inclusive treatment to the different actors in society, particularly to groups in a situation of vulnerability, promoting their equitable participation in decision-making (Urgenda Foundation $\mathrm{v}$ 
Netherlands, 2015; Ashgar Leghari v Pakistan, 2015; Declaration of Ethical Principles in relation to Climate Change, 2017, art 4).

\section{iv. The preventive principle}

This is a fundamental principle in the fight against climate change, which consists in the States' obligation to implement all types necessary of measures to prevent damage to the environment and common property. Its application has been given in the resolution of the International Court of Justice in the case of the cellulose factories along the Uruguay River (Elborough, 2017, pp.97-98).

The Law of the Sea Tribunal has considered that this principle must be applied in the context of the conditions prevailing in each case, that is, understanding the characteristics of each particular case (ITLOS, 2011, paras 115-117).

This principle applies to litigation on adaptation, which can discourage litigation on loss and damages, which is more focused on redress than prevention (Colombo \& Giadrossi, 2020).

\section{v. The precautionary principle}

Though controversial, this principle formulated in the Rio Declaration (1992, principle 15) provides that scientific certainty is not necessary for States to intervene when there are serious threats that irreversible damage to the environment may be caused (Bodansky et al., 2017, pp.43-44).

In fact, this principle is currently gaining status as customary international law. This can be seen in the advisory opinion of the Law of the Sea Tribunal in the Seabed Mining case (2011; Elborough, 2017, p.98).

\section{vi. The concept of sustainable development}

This principle implies an integral vision, in which the problem of climate change must be considered within the framework of sustainable development. To this end, it is necessary to guarantee the environment for the people who are living today and for those who will come in the future.

In addition, it is necessary to promote a better distribution of natural resources and to make the different actors in society aware of the importance of their conservation. It is equally important for the conditions of development to be guaranteed to the less favored populations (Declaration of Ethical Principles in relation to Climate Change, 2017, art 5).

\section{vii. The polluter pays principle}

Although it seems a logical rule that can be understood by anyone, the obligation to make the person responsible for the damage pay was not easy to establish in international law. Indeed, it was in the Rio Declaration on Environment and Development that this principle was established as a central pillar of environmental law.

In essence, this principle means that a polluting State or non-state actor, whether public or private, should be held responsible and be accountable for the reparation of the damage caused (Rio Declaration on Environment and Development, 1992, principle 16).

This principle has been criticized for its purely economic approach and its implications for the certainty of strict liability for the tortfeasor (Crawford, 2012, p.359).

\section{viii. The obligation of Environmental impact assessment}

This principle has a technical character. It aims to establish an obligation under international law to assess, to any possible extent, the environmental impact of a given decision. The intention is to avoid damage and, therefore, having to take corrective measures later. 
This principle is in the process of achieving status as a rule of customary international law (Mayer, 2019).

\section{ix. The principle of presumption}

This principle implies that the interpretation of national laws must be made in accordance with international obligations in order to indirectly apply international law (Rio Declaration on Environment and Development, 1992, principle 10; Urgenda v Netherlands, 2015).

\section{$x$. The principle of Climate Justice}

This principle involves moving away from environmental justice in general and towards a specific climate justice that is urgent and a priority. This principle was developed in the Leghari v Pakistan case (2015) and continued in the Urgeda v Netherlands case (2015) (Paris Agreement, 2015, preamble; Pernot, 2019).

\section{Legal resources that impact on the fight against climate change}

a. The international level

Under the United Nations Framework Convention on Climate Change (1992, art 14), national States have the following jurisdictional recourse: the contentious jurisdiction of the International Court of Justice. However, until today only the Republic of Cuba and the Kingdom of the Netherlands have recognized this jurisdiction of the International Court of Justice to submit their conflicts derived from the United Nations Framework Convention on Climate Change. The Solomon Islands, conversely, only recognizes the arbitration jurisdiction of the International Court of Justice to resolve disputes arising from the implementation of the United Nations Framework Convention on Climate Change (UN Treaty Collection, 2020; Murray, 2016; Elborough, 2017, pp.95-96).

Furthermore, we have the advisory jurisdiction of the International Court of Justice (UN News, 2011) and the mechanisms of the various treaty committees (Convention concerning the Protection of the World Cultural and Natural Heritage, 1972, art 4; Kyoto Protocol to the United Nations Framework Convention on Climate Change, 1997, art 7). So far, the only case brought to an international monitoring mechanism and the international arbitration procedures (Elborough, 2017, p.99; International Bar Association, 2014) is the UN Human Rights Committee, is the Torrest Strait Islanders in 2019 (UNHRC, 2020).

International courts are open to climate change litigation, but there is a lack of coordination to mitigate the problem (Elborough, 2017, pp.100-101). Although there is potential for interstate complaints, states prefer diplomatic solutions. In addition, the ambiguity of obligations, as well as the difficulty in determining the cause of damage and the multiplicity of actors, make State liability difficult (Elborough, 2017, pp.100-101).

We note two structural problems for international law to combat climate change: the first is the access to justice and the second is the effectiveness of remedies (Margaretha, 2019). In relation to the access to justice, while there have been advances in linking climate change and human rights (Paris Agreement, 2015, preamble), international forums for individuals are virtually limited to regional systems (Badrinarayna, 2018). Moreover, another procedural challenge enatils rethinking the concept of victim (Margaretha, 2019).

With respect to remedies, State responsibility presents technical difficulties to determine the harm caused. In the face of this complexity, the concept of probabilistic causation is beginning to emerge. According to this concept, it is sufficient to identify at least $50 \%$ of the contribution to the damage risk in order to determine responsibility for the damage caused (Elborough, 2017, p.99). 
There has been progress in World Trade Organization disputes, but a climate change approach to trade policy is needed (WTO, United States - Import Prohibition of Certain Shrimp and Shrimp Products - Appellate Body Report and Panel Report pursuant to Article 21.5 of the DSU - Action by the Dispute Settlement Body, WT/DS58/23, 26 November 2001; WTO, Brazil - Measures Affecting Imports of Retreaded Tyres - Status Report by Brazil - Addendum, WT/DS332/19/Add.6, 15 September 2009; WTO, Canada - Certain Measures Affecting the Renewable Energy Generation Sector - Communication from Canada WT/DS412/19 WT/DS426/19, 6 June 2014; WTO, China - Measures Concerning Wind Power Equipment - Request to join consultations - Communication from Japan WT/DS419/3, 19 January 2011; WTO, India - Certain Measures Relating to Solar Cells and Solar Modules - Recourse to article 21.5 of the DSU by India - Request for the establishment of a panel, WT/DS456/20, 29 January 2018). The rules in investment law must be rethought (Ethyl Corporation v The Government of Canada, 1997; Methanex Corporation v United States of America, 1999). Difficulties in this area arise from the absence of the doctrine of precedent and the lack of consensus on interpretative rules (Elborough, 2017).

\section{b. The regional level}

When considering the regional level of attention to climate change, we note that it is the regional human rights systems that have the greatest impact on the issue. We find the way of contentious jurisdiction that the national States have within each of the regional human rights jurisdictional bodies to be remarkable. However, it is important to point out that, according to the characteristics of each of these regional systems, not all national States that are part of the system accept the contentious jurisdiction of regional courts, but rather general or particular acceptance is required for regional courts to hear conflicts that may arise and have an impact on the fight against climate change. This makes it clear that on many occasions nation States do not accept the jurisdiction of regional bodies when they overlap with their national interests. Furthermore, with the exception of the African system, regional systems require that domestic remedies be previously exhausted.

We found that, to date, the American and European systems of human rights protection are the only ones that have received complaints about human rights violations due to climate change (Petition to the Inter-American Commission on Human Rights Seeking Relief from Violations of the Rights of Arctic Athabaskan Peoples Resulting from Rapid Arctic Warming and Melting Caused by Emissions of Black Carbon by Canada Submitted by the Arctic Athabaskan Council on Behalf of All Arctic Athabaskan Peoples of the Arctic Regions of Canada and the United States, 2013; Heri, 2020, December 22). We also note that it was within the African system, through the action of its jurisdictional body, that the right to a healthy environment was first pronounced at a regional level (ACHPR, 2001).

Other remedies include the consultative jurisdiction of regional courts as well as treaty monitoring mechanisms (IACHR, 2017).

\section{c. The national level}

At the national level, resources vary according to the political system of the country concerned and its involvement in the fight against climate change. We can distinguish between countries in the global north and south, the former being the most litigious. Most litigation occurs in developed countries, such as New Zealand, Australia, United Kingdom, United States, Netherlands and Austria, with the United States representing almost 2/3 of the world's litigation (Okonkwo, 2017).

In general, citizens have access to climate justice in four ways:

1) through environmental constitutionalism (Constitution of the Republic of South Africa, 1996, art 24; Constitution of the Republic of Costa Rica, 1949, art 50; Constitution of the Portuguese Republic, 2005, art $66)$; 
2) by means of the recognition of access to justice through the rules of international law (Rio Declaration on Environment and Development, 1992, principle 10; Urgenda v Netherlands 2015; Leghari v Pakistan 2015; Juliana v United States, 2018; Armando Ferrão Carvalho and Others v. The European Parliament and the Council, 2018);

3) through general rules of access to justice in codes or statutes (Climate Change Act UK, 2008; Climate Change Act NZ, 2002; Climate Change Act KE, 2014, art 23; Colombo, 2017);

4) through the compliance with the Nationally Determined Contributions that each State has committed to in the Paris Agreement (Hunter et al., 2019; Ariani, 2019), where we find two approaches:

i) litigation to mitigate climate change;

ii) litigation to reduce the budget of the fossil fuel industry (Hunter et al., 2019).

For such purpose, we have identified four national litigation groups:

1) those seeking a remedy against government inaction to mitigate air pollution;

2) those seeking a remedy for government action to contribute to climate change;

3) those seeking government approval for developments that contribute to climate change;

4) those seeking a remedy for the lack of government action to adapt to the consequences of climate change (Preston, 2018).

At the sub-national level, there are examples of heterodox actions: City of Los Angeles v. Nhtsa, 1990; Massachusetts v. Environmental Protection Agency, 2007; Greenpeace Australia Ltd v Redbank Power Pty Ltd, 1994; Ousley, 2019; Peel, Osofsky and Foerster, 2017. The difficulty of success in these actions is the absence of a uniform legal framework to respond to claims against acts causing climate change. Accountability, predictability and legal certainty must be improved in this area (Hester, 2018).

These lawsuits have been structured according to the following doctrines:

1) the state-created danger (Juliana v United States 2018; Johnson, 2019);

2) rights not explicitly listed in the constitution (Juliana v United States, 2018; Washington v Glucksberg, 1997);

3) public trust, used by complainants to demand the common use of the atmosphere (Kanuk ex rel. Kanuk v State, Dep't of Nat. Res., 2014; Sanders-Reed v Martinez, 2015; Juliana v United States, 2018; Foster v Wash. Dep't of Ecology, 2017; Funk v Wolf, 2017; Environment-People-Law v Cabinet of Ministers of Ukraine and National Agency of Environmental Investments, 2009; Segovia et., al. vs. the Climate Change Commission, 2017; Ali v. Federation of Pakistan, 2016; Ridhima Pandey v India, 2017);

4) the rights to life and to a quality environment.

Although domestic litigation is an option to combat climate change, its scope is limited, since it does not take a cross border approach, but rather constrains its effects on the people under its jurisdiction (Leghari $\mathrm{v}$ Paskitan, 2015; Urgenda v Netherlands, 2015; Margaretha, 2019).

The success of national litigation depends on structural and procedural aspects. The first group of factors, as Colombo (2017) points out, includes the nature of the legal system, the type of international norms involved, the type of legal provisions and the position of the national courts (Pernot, 2019). The greatest problems arise when national courts are faced with the impact of their rulings on national public policy (Ariani, 2019), as well as with the ambiguity of international norms. 
In the second group of factors, the success of the litigation depends on the possibility to identify the cause of the damage and for the complaint to pass the study of the merits, since this usually involves political problems that are difficult to overcome (Upadhyay, 2019; Palmer, 2018; Juliana v United States, 2018; Byers et al., 2017; Blumm \& Wood, 2017; Barnes, 2019).

There is a tendency to sue against the Carbon Majors. This strategy has proven to be straightforward and practical. The advantages of these processes are that there is greater predictability in the requirements to prove the cause of damage, as well as uniformity in the rules to determine the liability. Moreover, the possibility usually exists for a class action to be brought as well (La Vina \& Sy, 2019). And, finally, it should be noted that the actions against the Carbon Majors are critical given the importance that these actors have and their ability to pay for the damage caused (Barnes, 2019).

\section{Conclusions}

The fight against climate change could benefit from the emergence of transnational litigation, as well as from the implementation of legislation that expands the rules for access to justice.

Tort claims can be a useful tool in the absence of clear rules in international and domestic law (Byers et al., 2017). Arbitration processes are another possible solution (Elborough, 2017, p.96).

In addition, national courts must apply the climate change principles provided for in the Paris Agreement by implementing the concept of transnational public policy, since these are essential interests for everyone.

Moreover, the role of the International Court of Justice should be complementary to national jurisdictions. Similarly, human rights protection systems should be supplemental to the scheme provided for in the United Nations Framework Convention on Climate Change.

The fight against climate change must be coherent among the different actors and levels of incidence in order to be effective. However, while extremely important, climate justice alone cannot solve the problem of climate change, it must be accompanied by public awareness (Marjanac, 2020).

\section{Bibliography}

\section{a. Doctrine}

Bodansky, D., Brunnée, J. and Rajamani, L. (2017). International Climate Change Law. Oxford University Press.

Clapham, A. (2006). Human Rights Obligations of Non-State Actors. Oxford University Press.

Corten, O. (2009). Méthodologie du droit international public. Éditions de l'Université de Bruxelles.

Crawford, J. (2012). Brownlie's principles of Public International Law. 8th edition. Oxford University Press.

b. Papers

Ariani, D. (2019). The Effectiveness of Climate Change Litigation as a Venue to Uphold State Climate Change Obligations in Indonesia, Indonesian Journal of International Law, 16(2), 210-234.

Badrinarayna, D. (2018). A Constitutional Right to International Legal Representation: The Case of Climate Change, Tulane Law Review, 93(1), 47-104. 
Barnes, K. (2019). Democratizing Climate Change: Litigation for the Era of Extreme Weather, The University of the Pacific Law Review, 50(4), 651-684. https://scholarlycommons.pacific.edu/uoplawreview/vol50/iss $4 / 8$

Benoît, M. (2019). Climate Assessment as an Emerging Obligation Under Customary International Law, International and Comparative Law Quaterly, 68(2), 271-308.

Blumm, M. C. and Wood, M.C. (2017). "No Ordinary Lawsuit": Climate Change, Due Process, and the Public Trust Doctrine, The American University Law Review, 67(1), 1-87.

Byers, M., Franks, K. and Gage, A. (2017). The Internationalization of Climate Damages Litigation, Washington Journal of Environmental Law \& Policy, 7(2), 264-319. https://digitalcommons.law.uw.edu/wjelp/vol7/iss2/3

Colombo, E. (2017). Enforcing International Climate Change Law in Domestic Courts: A New Trend of Cases for Boosting Principle 10 of the Rio Declaration, UCLA Journal of Environmental Law \& Policy, 98-144.

Colombo, E., \& Giadrossi, A. (2020). Comparative International Litigation and Climate Change: A Case Study on Access to Justice in Adaptation Matters, University of Pittsburgh Law Review, 81(3), 527-596.

Elborough, L. (2017). International Climate Change Litigation: Limitations and Possibilities for International Adjudication and Arbitration in Addressing the Challenge of Climate Change, New Zealand Journal of Environmental Law, 21, 89-132.

Heri, C. (22 December 2020). The ECtHR's Pending Climate Change Case: What's Ill-Treatment Got To Do With It? EJIL: Talk! Blog of the European Journal of International Law. https://www.ejiltalk.org/the-ecthrs-pending-climate-change-case-whats-ill-treatment-got-todo-with-it/?utm_source=mailpoet\&utm_medium=email\&utm_campaign=ejil-talk-newsletterpost-title_2.

Hester, T. (2018). Climate Tort Federalism, FIU Law Review, 13(1), 79-101. https://dx.doi.org/10.25148/lawrev.13.1.8

Hunter, D. and Ji, W. and Rudock, J. (2019). The Paris Agreement and Global Climate Litigation after the Trump Withdrawal, Maryland Journal of International Law, 34(1), 224-248. https://digitalcommons.law.umaryland.edu/mjil/vol34/iss $1 / 9$

International Bar Association (2014). Achieving Justice and Human Rights in the Era of Climate Disruption. Climate Change Justice and Human Rights Task Force Report. https://www.ibanet.org/PresidentialTaskForceClimateChangeJustice2014Report.aspx

Johnson, A. (2019). Life, Liberty, and a Stable Climate: The Potential of the State-Created Danger Doctrine in Climate Change Litigation, American University Journal of Gender, Social Policy \& the Law, 27(4), 585-611. https://core.ac.uk/download/pdf/288206246.pdf

La Vina, A. y Sy, J. (2019). Achieving Climate Justice through Tort Law: Issues and Challenges, Ateneo Law Journal, 63(4), 1042-1082.

Marjanac, S. (2020). The Role of Climate Change Litigation: Interview with Sophie Marjanac, Interviewed by Andy Symington, Human Rights Defender, 29(3), 26-28.

Murray, C. (2016). The geopolitics of climate justice: collective interest or raison de système?, Journal of Energy \& Natural Resources Law, 34(1), 109-125. https://doi.org/10.1080/02646811.2016.1120581 
Okonkwo, T. (2017). Protecting the Environment and People from Climate Change through Climate Change Litigation, Journal of Politics and Law, 10(5), 66-77. https://doi.org/10.5539/jpl.v10n5p66

Ousley, M. H. (2019). Precedent, Politics, Or Priorities: Are Courts Stepping out of Their Traditional Judicial Bounds When Addressing Climate Change, Hastings Environmental Law Journal, 25(2), 349374. https://repository.uchastings.edu/hastings_environmental_law_journal/vol25/iss2/7/

Palmer, G. (2018). Can Judges Make a Difference: The Scope for Judicial Decisions on Climate Change in New Zealand Domestic Law, Victoria University of Wellington Law Review, 49, 191-210. http://www.nzlii.org/nz/journals/VUWLawRw/2018/8.pdf

Peel, J. and Osofsky, H. and Foerster, A. (2017). Shaping the Next Generation of Climate Change Litigation in Australia, Melbourne University Law Review, 41(2), 793-844. https://law.unimelb.edu.au/_data/assets/pdf_file/0005/2771447/10-Peel,-Osofsky-and-Foerster.pdf

Pernot, E. (2019). The Right to an Environment and Its Effects for Climate Change Litigation in Ireland, Trinity College Law Review, 22, 151-172. https://ie.vlex.com/vid/the-right-to-an-852253463

Preston, B. J. (2018). The Evolving Role of Environmental Rights in Climate Change Litigation, Chinese Journal of Environmental Law, 2(2), 131-164. https://doi.org/10.1163/24686042-12340030

UNHRC (2019). Communication No 3585/2019, Australia (pending). https://www.ohchr.org/EN/HRBodies/CCPR/Pages/TableRegisteredCases.aspx

United Nations (September 22, 2011). Palau Seeks UN World Court Opinion on Damage Caused by Greenhouse Gases. http://www.un.org/apps/news/story.asp?NewsID=39710

Upadhyay, P. (2019). Climate Claimants: The Prospects of suing the New Zealand Government for Climate Change Inaction, New Zealand Journal of Environmental Law, 23, 187-213.

Wewerinke-Singh, M. (2019). Remedies for Human Rights Violations Caused by Climate Change, Climate Law, 9(3), 224-243. https://doi.org/10.1163/18786561-00903005

c. Legislation and Cases

African Commission on Human and Peoples' Rights (2001). Communication 155/96. The Social and Economic Rights Action Center and the Center for Economic and Social Rights $v$ Nigeria. https://www.achpr.org/public/Document/file/English/achpr30_155_96_eng.pdf

Armando Ferrão Carvalho and Others v. The European Parliament and the Council (8 May 2018). ECLI:EU: T:2019:324 (People's Climate Case).

Ashgar Leghari v Federation of Pakistan. September 14, 2015.W.P. No. 25501/2015.

Case concerning Pulp Mills on the River Uruguay (Argentina v Uruguay) (Judgment). 2010. ICJ Rep 14, 55.

City of Los Angeles v. Nhtsa, 912 F.2d 478 (D.C. Cir. 1990).

Climate Change Act 2002 (New Zealand).

Climate Change Act 2008 (United Kingdom).

Climate Change Act 2014 (Kenya).

Constitution of the Portuguese Republic. 2005.

Constitution of the Republic of Costa Rica. 1949. 
Constitution of the Republic of South Africa. 1996.

Convention concerning the Protection of the World Cultural and Natural Heritage (1972).

Declaration of Ethical Principles in relation to Climate Change (2017).

Declaration of the United Nations Conference on the Human Environment (1972).

Dep’t of Nat. Res., 335 P.3d 1088, 1092. Kanuk ex rel. Kanuk v State. (Alaska 2014).

Foster v Wash. Dep't of Ecology, No. 75374-6-I (Wash. Ct. App. Sep. 5, 2017).

Funk v Wolf, 158 A.3d 642 (Pa. 2017).

Greenpeace Australia Ltd v Redbank Power Pty Ltd (1994) 86 LGERA 143.

I/A Court H.R., Advisory Opinion OC-23/17 of November 15, 2017, requested by the Inter-American Court of Human Rights. Republic of Colombia on the environment and human rights, OC-23/17. November 15, 2017. https://www.refworld.org.es/docid/5ade36fe4.html

Juliana v United States, 339 F. Supp. 3d 1062, 1105 (D. Or. 2018).

Kyoto Protocol to the United Nations Framework Convention on Climate Change (1997)

Legality of the Threat or Use of Nuclear Weapons (Advisory Opinion) (1996) ICJ Rep 226. 242 (para 29).

Lviv Circuit Admin. Court. Environment-People-Law v Cabinet of Ministers of Ukraine and National Agency of Environmental Investments (2009).

Massachusetts v. Environmental Protection Agency, 549 U.S. 497, 127 S. Ct. 1438, 167 L. Ed. 2 d 248 (2007).

Paris Agreement (2015).

Petition to the Inter-American Commission on Human Rights Seeking Relief from Violations of the Rights of Arctic Athabaskan Peoples Resulting from Rapid Arctic Warming and Melting Caused by Emissions of Black Carbon by Canada Submitted by the Arctic Athabaskan Council on Behalf of All Arctic Athabaskan Peoples of the Arctic Regions of Canada and the United States (2013) (pending). http://blogs2.law.columbia.edu/climate-change-litigation/wp-content/uploads/sites/16/non-us-case-documents/2013/20130423_5082_petition.pdf

Responsibilities and Obligations of States Sponsoring Person and Entities with Respect to Activities in the Area (Advisory Opinion, Order of 1 February 2011) ITLOS Reports 2011, 10 (Responsibilities in the Area).

Rio Declaration on Environment and Development (1992).

Sanders-Reed v Martinez, 350 P.3d 1221, 2015 NMCA 63 (N.M. Ct. App. 2015).

Segovia et., al. vs. the Climate Change Commission, ey., al., G.R. No. 211010, 7 March 2017.

Supreme Court of Pakistan. Ali v. Federation of Pakistan (2016); Ridhima Pandey v India. March 2017.

The United Nations Commission on International Trade Law. Ethyl Corporation v The Government of Canada, (1997).

The United Nations Commission on International Trade Law. Methanex Corporation v United States of America, (1999).

United Nations Framework Convention on Climate Change (1992). 
United Nations Treaty Collection, 7. United Nations Framework Convention on Climate Change, Status as at December 29, 2020 11:15:24 EDT. https://treaties.un.org/Pages/ViewDetailsIII.aspx?src=IND\&mtdsg_no=XXVII-7\&chapter $=27 \&$ Temp $=$ mtdsg $3 \&$ clang $=\_$en\#EndDec

Urgenda Foundation v The Kingdom of the Netherlands (2015) HAZA C/09/00456689 (June 24, 2015).

Washington v. Glucksberg, 521 U.S. 702, 117 S. Ct. 2258 (1997).

WTO, Brazil, Measures Affecting Imports of Retreaded Tyres. Status Report by Brazil. Addendum, WT/DS332/19/Add.6. 15 September 2009.

WTO, Canada, Certain Measures Affecting the Renewable Energy Generation Sector. Communication from Canada WT/DS412/19 WT/DS426/19. 6 June 2014.

WTO, China. Measures Concerning Wind Power Equipment. Request to join consultations. Communication from Japan WT/DS419/3. 19 January 2011.

WTO, India. Certain Measures Relating to Solar Cells and Solar Modules. Recourse to article 21.5 of the DSU by India - Request for the establishment of a panel, WT/DS456/20. 29 January 2018.

WTO, United States. Import Prohibition of Certain Shrimp and Shrimp Products. Appellate Body Report and Panel Report pursuant to Article 21.5 of the DSU. Action by the Dispute Settlement Body, WT/DS58/23. 26 November 2001. 